\title{
A new name for a widespread and misunderstood species of Verbena (Verbenaceae)
}

\author{
P.W. Michael
}

\begin{abstract}
Michael, P.W. (National Herbarium of New South Wales, Royal Botanic Gardens, Sydney, Australia 2000) 1995. A new name for a widespread and misunderstood species of Verbena (Verbenaceae). Telopea 6(2-3): 181-183. Verbena incompta, a species of presumed South American origin now widespread in sub-tropical and warm-temperate regions and especially prominent in eastern New South Wales, is described. Features distinguishing it from $V$. bonariensis L. and from $V$. brasiliensis as illustrated in Yeo (1990) are presented.
\end{abstract}

The widespread species of Verbena, with stem-clasping leaves, described here was recognised by Yeo (1990) as being distinct from $V$. bonariensis L. sensu stricto. Yeo convincingly typified the latter and presented a good illustration of it, showing its long flowers conspicuously overtopping the apex of the spikes, just as in the lectotype (LINN 35.11, seen in microfiche) and in the illustration in Dillenius referred to by Linnaeus. At first, he contemplated describing the former as a new species but eventually decided to include it in a widened concept of $V$. brasiliensis Vell. embracing forms with stem-clasping leaves and forms with subpetiolate leaves. However, he chose to illustrate only specimens with subpetiolate leaves. Yeo's treatment has been followed by Verdcourt (1992), with some reservations, and Green (1994).

I have observed the species in question in the field in coastal New South Wales where it is quite common, often locally abundant, sometimes occurring together with $V$. bonariensis under which name it has been usually known. Plants with subpetiolate leaves and close ascending inflorescences, known as $V$. brasiliensis, also occur in eastern Australia; these are usually $2 \mathrm{~m}$, sometimes more than $3 \mathrm{~m}$, tall. The detailed features of Yeo's illustration and the description and illustration by Vellozo $(1825,1831)$ of the stature and leaf-shape of these tall plants, underlie my opinion that $V$. brasiliensis is distinct from the species described. here. Proper typification of $V$. brasiliensis Vell., however, demands further study

\section{Verbena incompta Michael sp. nov.}

$V$. bonariensi L. affinis sed floribus minoribus infra summa spicarum circulatim dispositis interdum summa parum excedentibus, bracteis calycibus pedunculisque non glandulis stipitatis copiose conspersis, staminibus superioribus certe tubo corollae supra medium insertis, nuculis brevioribus, differt.

A $V$. brasiliensi ut in Yeo (1990) illustrato foliis plusminusve amplexicaulis nec subpetiolatis, spicis maturis latioribus, antheris superioribus a fauce corollae aliquanto distanter dispositis, distinguitur.

[Like $V$. bonariensis but with smaller flowers arranged in a circle below the top of the spikes, sometimes slightly exceeding the tops, bracts, calyces and peduncles not generously sprinkled with stalked glands, with upper stamens clearly inserted above the middle of the tube of the corolla and with shorter nutlets. 
Distinguished from $V$. brasiliensis as illustrated in Yeo (1990) with its leaves more or less amplexicaul and not subpetiolate, spikes wider at maturity and with the upper anthers situated at some distance below the throat of the corolla.]

Holotype: Victoria: Bright-Tawonga Rd. 6 miles $(9.7 \mathrm{~km})$ ESE of Bright, c. 2 miles $(3.2 \mathrm{~km}) \mathrm{E}$ of Tawonga-Harrietville road fork, R.V. Smith 64/64, 25 March 1964 (MEL); isotype NSW.

Icones: Shu-Miaow Chaw et al. (1986) Fig. 1 (as $V$. bonariensis)

Auld and Medd (1987) p. 236 (as V. bonariensis)

Lamp and Collet (1976) no. 273 p. 342 (as V. bonariensis).

Erect perennial herb generally $0.5 \mathrm{~m}$ to $1.5 \mathrm{~m}$ tall, sometimes approaching $2 \mathrm{~m}$, frequently branching from the base. Stems sharply 4-angled with prominent long hairs. Leaves decussate, lower ones in largest plants up to $15 \mathrm{~cm}$ long, more or less amplexicaul, sometimes subauriculate, lanceolate, often quite broad (up to $30 \mathrm{~mm}$ ) in the middle, sharply and irregularly serrate for the greater part of their length, becoming entire towards the base, scabrous on both surfaces with short more or less appressed hairs, longer hairs prominent along principal veins beneath. Inflorescence corymbose-spicate, wherever branching subtended by a pair of lanceolate, acuminate bracts. Spikes 3 to 10 in number, up to about $5 \mathrm{~mm}$ broad and $5(-7) \mathrm{cm}$ long at maturity. Flowers many, compact, opening together in a circle immediately below the apex of the spike, sometimes slightly exceeding the apex. Floral bracts ovate-lanceolate, 2 to $3 \mathrm{~mm}$ long, acuminate at apex occasionally with a few stipitate glands among the short and longer hairs. Calyx tube pubescent, angled about 2.5 $\mathrm{mm}$ long, 5-toothed. Corolla tube slightly curved, blue to reddish-purple, 2.5 to 3.5 $\mathrm{mm}$ long, puberulent outside beyond the calyx and inside around the throat, lobes 5 about $0.8 \mathrm{~mm}$ long. Upper pair of stamens inserted well above middle of tube; upper anthers situated in upper third of tube, clearly below the throat. Fruit included in the persistent calyx tube; nutlets 1.3 to $1.5 \mathrm{~mm}$ long ribbed on outside, weakly reticulate at the distal end with verrucose papillae abundant on their inner (commissural) faces.

$V$. incompta is of presumed South American origin and is now widely distributed in moist places in sub-tropical and warmer temperate parts of the world. In Australia, it is most prominent in eastern New South Wales.

Etymology: The epithet is derived from the Latin incomptus, untrimmed, referring to the untidy aspect of the plants themselves (often with dead branches and dried spikes amongst the new growth of stems, leaves and flowers) and the untidy places in which they are often found.

Selected specimens: Brazil: Rio Grande do Sul-Porto Alegre - ad fossas frequent, Reineck s.n., Dec 1898 (NSW).

South Africa: Transvaal: Nylsvlei Nature Reserve, Retief 1592, Dec 1984 (NSW ex PRE).

Papua New Guinea: Irokaieta, Ialibu subdistrict, 06 $10^{\prime} \mathrm{S} 146^{\circ} 50^{\prime} \mathrm{E}$, Conn LAE 69482, Orchard \& Kakavara, Dec 1975 (NSW).

Fiji: Rewa River, Seeman s.n. (MEL).

New Zealand: North Island, Manakau Co., 10k ESE of Clevedon, Orchard 3280, 1972 (NSW ex $\mathrm{AK})$.

Norfolk Island: Maiden \& Boorman, Nov 1902 (NSW).

Australia: Queensland: Port Denison (Bowen), Dietrich s.n., 1870-3 (MEL) Mt. Morgan, Michael s.n., May 1972 (NSW); On the banks of the Brisbane River, Dr M. [F. Mueller] s.n., Dec 1856 (MEL); Toowoomba, Hood s.n., 1886 (MEL); Tanduringie, $12 \mathrm{~km}$ NNW of Cooyar, 21 $53^{\prime} \mathrm{S}$ $151^{\circ} 47^{\prime}$ E, Pedley 5637, Jan 1992 (AD, NSW). 
New South Wales: Lord Howe Island: Lagoon Beach, hind dune opposite 'Pine Trees', Pickard 2694, Dec 1975 (NSW). North Coast: Richmond River, Hodgkinson s.n., 1874 (MEL); Gloucester, Coveny 664, Dec 1968 (NSW); North Arm of Wollombi Brook Bridge, Millfield on CessnockWollombi Road, Coveny 6514 \& Powell, June 1975 (NSW). Central Coast: Flemington Sale Yards, Michael s.n., Nov 1969 (NSW, CANB). South Coast: Wollongong, Macpherson s.n., 1889 (MEL). Northern Tablelands: Tenterfield, Stuart, Jan 1871 (MEL). Central Tablelands: 'Goolloinboin' on Glen Davis Rd., Capertee, Bryant 13, Jan 1975 (NSW); 24.5 km NE of Blayney PO between Dicks Ck and Evans Plains, Coveny 12581, Bishop \& Dalby, April 1988 (NSW). Southern Tablelands and Australian Capital Territory: Coppins Crossing on Molonglo River $3.6 \mathrm{~km} \mathrm{SSW}$ of Cook PO, Coveny 11578 \& Hind, Jan 1983 (NSW). South Western Plains: Roadside, Leeton township, Auld 120073, Nov 1980 (voucher specimen for photograph in Auld \& Medd (1987)) (NSW).

Victoria: $32.8 \mathrm{~km}$ SSE of Omeo on road to Bairnsdale, Cullimore 259, Jan 1968 (MEL, NSW); Banks of Yarra River, Heidelberg, Reader s.n., Mar 1883 (MEL); Dartmoor, c. 60 km NW of Portland between railway crossing and bridge over Glenelg River, Beauglehole 4966, Jan 1959 (AD, MEL); Echuca Regional Pk, Beauglehole 80268, Sep 1985 (MEL).

South Australia: Onkaparinga River bed near Clarendon, L.D. Williams 4110, Mar 1972 (AD).

Northern Territory: Port Darwin, Holtze s.n., 1888 (MEL).

\section{Acknowledgement}

I am grateful to Max Gray, who first drew my attention to Yeo's paper and who continually encouraged me to persevere with a problem which seemed daunting.

\section{References}

Auld, B.A. \& Medd, R.W. (1987) Weeds. An illustrated botanical guide to the weeds of Australia (Inkata Press: Melbourne).

Green, P.S. (1994) Verbenaceae. Flora of Australia 49: 312-316.

Lamp, C. \& Collet, F. (1976) A Field Guide to Weeds in Australia (Inkata Press: Melbourne).

Chaw, Shu-Miaw, Peng, Ching-I \& Kao, Muh-Tsuen (1986) Verbena bonariensis L. (Verbenaceae):

A Newly Naturalized Plant in Taiwan. Journal of Taizwan Museum 39(2): 123-126.

Vellozo, J.M. da C. (1825) Florae Fluminensis.

Vellozo, J.M. da C. (1831) Florae Fluminensis, Icones Vol. 1.

Verdcourt, B. (1992). Verbenaceae. Flora of Tropical East Africa.

Yeo, P.F. (1990). A re-definition of Verbena brasiliensis. Kew Bulletin 45(1): 101-120. 